\title{
CONICAL FOLDS IN THE HITOYOSHI BENDING, SOUTH KYUSHU, FORMED BY THE GLOGKWISE ROTATION OF THE SOUTHWEST JAPAN ARC
}

\author{
AkIHIRo MURATA*
}

\begin{abstract}
The bending from the Southwest Japan Arc toward the Nansei-Shoto Arc occurs in South Kyushu as an assemblage of three bendings, Hokusatsu, Hitoyoshi, and Nojiri Bendings. Among them, strike swings of the Shimanto Supergroup and Hyuga Group are mapped in detail in the Hitoyoshi Bending Area. Geometrical analyses have revealed that mappable fold structures forming the strike swings are conical folds with vertical cone axes. The conical folds were formed by cylindrical folding of previously dipping bedding surfaces. The cylindrical folding with vertical axes which means a rotation in plan probably occurred contemporaneously at the time of the Miocene clockwise rotation of the Southwest Japan Arc.
\end{abstract}

\section{Introduction}

South Kyushu is situated in the junction area between the Southwest Japan Arc trending in the ENE-WSW direction and the Nansei-Shoto Arc trending in the NNE-SSW direction, and roughly lies on the landward side of the triple junction area among the Nankai Trough, the Nansei-Shoto Trench, and the Kyushu-Palau Ridge. There the PermoJurassic Sambosan, Gretaceous Shimanto, and Paleogene Hyuga Terrains striking $\mathrm{N} 40^{\circ}-60^{\circ} \mathrm{E}$ in the Southwest Japan Arc sharply bend toward $\mathrm{N} 10^{\circ}-20^{\circ} \mathrm{E}$, and can be traced toward the Nansei-Shoto Arc (Fig. 1).

The bending from the Southwest Japan Arc toward the Nansei-Shoto Arc is not formed as a single large bending, but formed as an assemblage of three bendings, Hokusatsu Bending, (Наsнimoto, 1962a, b), Hitoyoshi Bending, and Nojiri Bending (Teraoka et al., 1981) (Fig. 1). The Sambosan Terrain and the northern half of the Shimanto Terrain are bent by the Hokusatsu Bending, and the southern half of the Shimanto Terrain and the

Received December 13, 1985. Accepted November 17, 1986.

* Geological Institute, Faculty of Science, University of Tokyo, Tokyo, 113 Japan. northern half of the Hyuga Terrain are bent by the Hitoyoshi Bending. And the southern half of the Hyuga Terrain is mainly bent by the Nojiri Bending ('Teraoka et al., 1981)(Fig. $1)$.

The clockwise rotation of the Southwest Japan Arc is commonly expressed to have occurred associated with the opening of the Sea of Japan. There were several ideas on the age of the opening; that is, Cretaceous (HrLde \& Wageman, 1973), Cretaceous to Paleogene (Honza, 1979), Paleogene (Kimura, 1974), and Miocene (Kobayashi, 1956; Kaseno, 1972). However, recent vigorous paleomagnetic studies revealed that the Southwest Japan Arc mainly rotated clockwise about $47^{\circ}$ in the Middle Miocene (Torir et al., 1985).

There were, however, little studies on geologic structures associated with the bendings in South Kyushu, except for Hashrmoto(1962 a, b) and Teraoka et al. (1981). I have firstly confirmed conical folds of the mappable scale with vertical cone axes in the Hitoyoshi Bending Area by means of minute mapping and bedding surface analyses. The conical folds were formed by cylindrical folding of previously dipping bedding surfaces. The cylindrical folding with vertical axes which means a rotation in plan probably occurred 


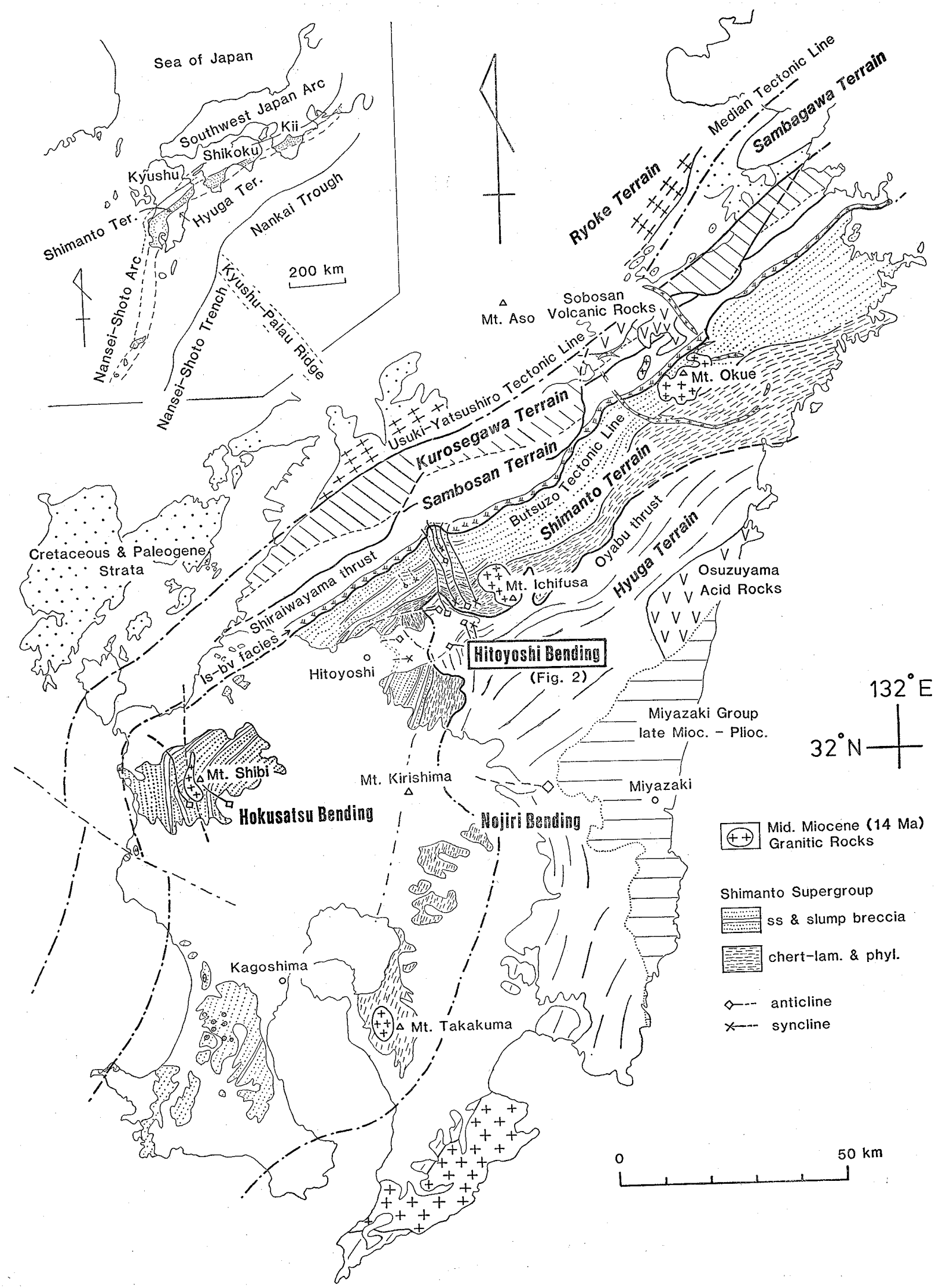

Fig. 1. Geologic map of Kyushu showing three Bendings. 
contemporaneously at the time of the clockwise rotation of the Southwest Japan Arc associated with the opening of the Sea of Japan.

\section{Geologic setting}

South of the high T/P type Ryoke Metamorphic Terrain lie the Kurosegawa and Sambosan Terrains in the most part of Kyushu, bounded by the Usuki-Yatsushiro Tectonic Line which is partly a western extension of the Median Tectonic Line. The high $\mathrm{P} / \mathrm{T}$ type Sambagawa Metamorphic Terrain and the Chichibu Terrain do not lie in Kyushu except in its eastern extremity, although they are main constituents in the Outer Zone of Southwest Japan.

The Kurosegawa Terrain is an old island arc (KImura, 1974), and includes various kinds of rocks of pre-Silurian to Cretaceous age. Serpentinites, pre-Silurian granitic and metamorphic rocks, Siluro-Devonian reef limestones and acid tuffs, and Permian to Cretaccous sedimentary rocks of shallow facies are main constituents of the Terrain. The Sambosan Terrain is a narrow sedimentary basin of Permian to Jurassic age. Strata dominant with limestones and basic volcanics occur in the southern marginal part of the Sambosan Terrain (Fig. 1). There are large overthrusts, the Shiraiwayama thrust and the Butsuzo Tectonic Line, in and along the southern margin of the Sambosan Terrain. The Shiraiwayama thrust moved the rocks and strata of the Kurosegawa Terrain and northern Sambosan Terrain toward south as the Shiraiwayama nappe (Murata, 1981). The Butsuzo Tectonic Line moved the limestones and basic volcanics of the Sambosan Terrain toward south over the Shimanto Supergroup (Fig. 1).

The Shimanto Terrain and the Hyuga Terrain are narrow sedimentary basins of mainly Cretaceous and Paleogene to Earliest Miocene age respectively. They are mainly composed of sandstone-dominant strata and slump breccia (olistostrome)-dominant strata, accompanied by chert and basic volcanics olistoliths. The Shimanto Supergroup is thrust over the Hyuga Group along the Oyabu thrust (NoDA $\&$ Hashimoto, 1958).
The Hyuga Group is overlain by the Miyazaki Group of Latest Miocene to Pliocene age clino-unconformably (Shuto, 1963). The Miyazaki Group can be traced seaward and occupies the lower part of the deposits of the Hyuga basin, which is a part of the Miocene to recent forearc basin (Okuda, 1984). The Sambosan, Shimanto, and Hyuga Terrains are intruded by the granitic rocks of about $14 \mathrm{Ma}$, which occur sporadically in the Outer Zone of Southwest Japan (Shibata, 1978) (Fig. 1).

\section{Stratigraphy of the Shimanto Terrain}

The Shimanto Supergroup of the Hitoyoshi Bending Area is divided into two groups, Tashiro and Nonowaki Groups. The Tashiro Group is mainly composed of chert-laminite (Yoshida, 1982) and phyllite with schistose sandstone, and is possibly in fault contact with the Nonowaki Group. The Nonowaki Group is composed of two formations, sandstone-dominant formation and slump breccia-dominant formation.

\section{Tashiro Group}

The Tashiro Group occurs from the Ichifusa Dam to Tashiro, and from Saginosu to $\mathrm{Mt}$. Shiraga-dake (Fig. 2). Type locality of the group is a road-cut along the Kawabe River to the south of Tashiro. The Tashiro Group roughly corresponds to the Nagase, Makimine and Yato Formations and a part of the Mikado Formation of TERAokA et al. (1981). The group possibly corresponds to the Kitagawa Group and a part of the Morotsuka Group (SAKai \& Kanmera, 1981) in the Hyuga area.

The Tashiro Group is composed of chertlaminite, phyllite, and schistose sandstone with a small amount of slump breccia, basic volcanics, chert, and red shale. The group has undergone metamorphism of actinolite facies (Teraoka et al., 1981), and is metamorphosed into so-called semi-schist with many quartz veins.

The chert-laminite is thinly alternating beds of chert and mudstone of $0.1 \mathrm{~mm}$ to $5 \mathrm{~mm}$ thick. The phyllite is made up of minute sericite and chlorite, and is very fissile. The schistose sandstone is made up of quartz and 


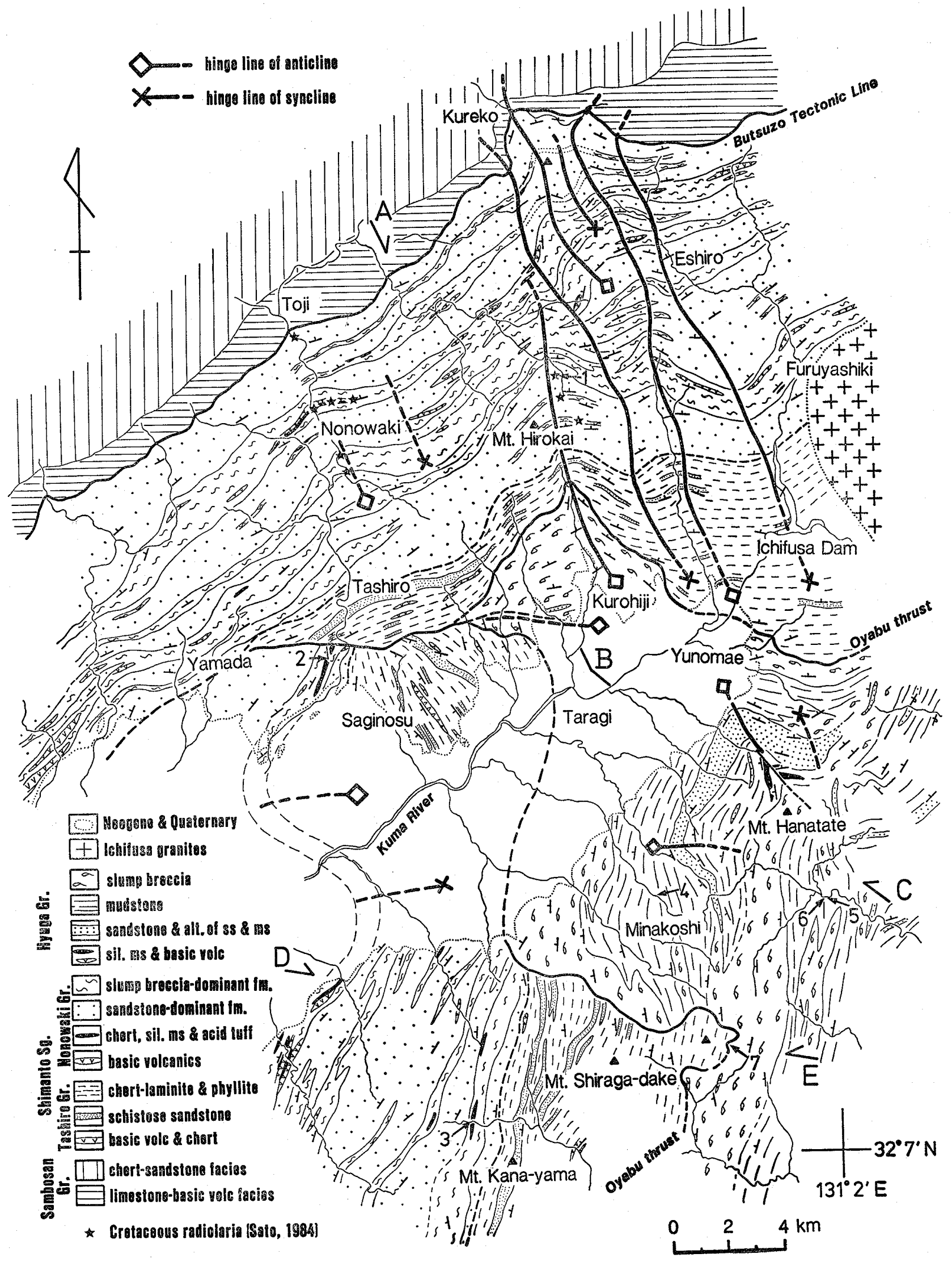

Fig. 2. Geologic map of the Hitoyoshi Bending Area. 
Table 1. Cretaceous radiolarians from the Hitoyoshi Bending Area. Identified by M. AdAGHI and H. Yoshida.

\begin{tabular}{|l|l|l|}
\hline Loc./rock & \multicolumn{1}{|c|}{ radiolarians } & \multicolumn{1}{|c|}{ assemblage/age } \\
\hline $\begin{array}{l}\text { Loc. I } \\
\text { acid tuff }\end{array}$ & $\begin{array}{l}\text { Pseudodictyomitra pseudomacrocephla, } \\
\text { Thanarla veneta, T. elegantissima, } \\
\text { Holocryptocanium barbui, } \\
\text { Praeconocaryomma sp. }\end{array}$ & $\begin{array}{l}\text { Holocryptocanium barbui - } \\
\text { H. geysersensis Assemblage } \\
\text { Albian - Cenomanian }\end{array}$ \\
\hline $\begin{array}{l}\text { Loc. } 2 \\
\text { red chert }\end{array}$ & $\begin{array}{l}\text { Thanarla sp., Dictyomitra sp., } \\
\text { Archaeospongoprunum sp., } \\
\text { Ultranapora sp., spongosaturnalis spp. }\end{array}$ & $\begin{array}{l}\text { Acaeniotyle umblicate - Ultranapora } \\
\text { praespinifers Assemblage } \\
\text { Aptian }\end{array}$ \\
\hline $\begin{array}{l}\text { Loc. 3 } \\
\text { acid tuff }\end{array}$ & $\begin{array}{l}\text { Dictyomitra koslovae, D. cf. formosa, } \\
\text { Amphipyndax cf. stocki, Alievium sp., } \\
\text { Praeconocaryomma sp., Carpocanopsis } \\
\text { Cf. costatum }\end{array}$ & $\begin{array}{l}\text { Artollule planoconvexa - } \\
\text { Coniacian - Santonian }\end{array}$ \\
\hline
\end{tabular}

feldspar grains and matrix of aggregate of minute quartz and mica minerals. The slump breccia is made up of sandstone breccia and chert-laminite matrix. The basic volcanics are tuff and pillow lava, and include titanaugite as a relict mineral and chlorite, actinolite, and albite as metamorphic minerals. The chert is red and bedded, and is made up of oblate fine quartz aggregate. The Tashiro Group yields no fossils except for deformed radiolarians in the bedded chert.

\section{Nonowaki Group}

The Nonowaki Group is widely distributed from Eshiro to Nonowaki, and to the west of Mt. Shiraga-dake. Type locality is a roadcut along the Kawabe River near Nonowaki. The group roughly corresponds to the Tonegawa, Shiiba, and Hinokage Formations of Teraoka et al. (1981), and the Hinokage and Makimine Formations of SAKAI \& KanMERA (1981) in the Hyuga area. The Nonowaki Group is composed of two formations, sandstone-dominant one and slump breccia-dominant one. The former laterally changes into the latter, and they interfinger with each other.

The sandstone-dominant formation is mainly composed of sandstone, alternating beds of sandstone and mudstone, and mudstone, and is accompanied by conglomerate, siliceous mudstone, and acid tuff. The sandstone is coarse- to medium-grained, ill-sorted wacke. It includes many lithic fragments in places, which are mainly acid volcanic ones. The alternating beds of sandstone and mudstone are rhythmical one of sandstone bed, $5 \mathrm{~cm}$ to $1 \mathrm{~m}$, and mudstone bed, $1 \mathrm{~cm}$ to $30 \mathrm{~cm}$. The sandstone bed in the alternation shows graded bedding in places. The mudstone is mainly greyish black colored siltstone with sandy laminae.

The pebble conglomerate with sandy matrix occurs to the south of Nonowaki and to the west of Saginosu. The pebbles are wellrounded, and are mainly made up of acid igneous rocks and sandstone. The siliceous mudstone is greenish grey colored and changes gradually into the mudstone. The siliceous mudstone includes many ill-preserved radiolarians. It is accompanied by acid tuff in the area to the north of Tashiro and to the west of Saginosu, which shows clear vitroclastic texture.

The slump breccia-dominant formation is mainly composed of slump breccia, mudstone, basic volcanics, chert, siliceous mudstone, and chert-laminite. The slump breccia is made up of mainly S-sized ( $\leqq 1 \mathrm{~m}$ ) to L-sized (10$100 \mathrm{~m}$ ) sandstone breccia (KImURA, 1979, p. 412) and muddy matrix. The mudstone is greyish black colored and phyllitic in places. The siliceous mudstone is associated with the mudstone, and is pale green colored and fissile. The chert-laminite rarely occurs near Furuyashiki. The chert is red and grey colored, and bedded radiolarian one. It is associated with the basic volcanics in most cases, and is surrounded by the slump breccia. The 
basic volcanics are pillow lava and tuff. The volcanics include titanaugite as a relict mineral and chlorite, pumpellyite, albite as metamorphic minerals. The chert and basic volcanics are possibly large slump blocks in the slump breccia-dominant formation.

Some well preserved radiolarian fossils are obtained from the red chert (Loc. 2) and acid tuff (Loc. 3) of the slump breccia-dominant formation, and from the acid tuff (Loc. 1) of the sandstone-dominant formation (Fig. 2 and Table 1). The radiolarians at Locs. 2, 3, and 1 are assigned to Acaeniotyle umblicate-Ultranapora praespinifers Assemblage (Aptian), Patellule planoconvexa-Artostorobium urna Assemblage (Coniacian-Santonian), and Holocryptocanium barbui - H. geysersensis Assemblage (Albian-Cenomanian) of NAKASEKo \& Nishimura (1981) respectively. Gretaceous radiolarians have been reported by SAтo (1984) at some localities near Nonowaki and Mt. Hirokai (star in Fig. 2). They are all assigned to Holocryptocanium barbui- $H$. geysersensis Assemblage of NAkaseko \& Nishimura (1981). The Nonowaki Group ranges in age from Aptian to Santonian.

\section{Stratigraphy of the Hyuga Terrain}

The Hyuga Group of the Hitoyoshi Bending Area widely occurs in the area southeast and north of Taragi (Fig. 2). The group mainly consists of sandstone, mudstone, alternating beds of sandstone and mudstone, and slump breccia. The group is accompanied by minor amount of siliceous mudstone and basic volcanics which are possibly large blocks of slump breccia mentioned later.

The sandstone is grey to white-grey colored, and characteristically reddish purple colored on weathered surface. It is massive, coarseto medium-grained, and well-sorted. The sandstone is quartzose arenite (TERAOKA et al., 1981).

The mudstone is dark grey colored, and contains sandy lamina. The alternating beds of sandstone and mudstone consist of sandstone layer of 10 to $100 \mathrm{~cm}$ thick and mudstone layer of 5 to $30 \mathrm{~cm}$ thick. The sandstone layer in the alternating beds frequently shows graded bedding.

The slump breccia is widely distributed along the Oyabu thrust, and is mainly originated from the alternation of sandstone and mudstone. It was considered to be sheared rocks associated with the thrust (TERAOKA et al., 1981) or slump breccia (OGAWAUchI et al., 1984). I have the same opinion with Ogawauchi et al. (1984), because it is not sheared in most cases and has clasts of irregular shapes. Clasts are made up of sandstone preserving bedding surface, and they are $10 \mathrm{~cm}$ to a few meters in length.

The siliceous mudstone occurs to the north of Mt. Hanatate. It is pale green and red colored, and includes slightly deformed radiolarians. The basic volcanics occur in the area south of Mt. Shiraga-dake, and consist of lava and tuff. The siliceous mudstone and the basic volcanics are probably large submarine sliding blocks, because they occur sporadically, surrounded by the slump breccia.

The slump breccia and sandstone in the area north of Taragi were once assumed to be the Shimanto Supergroup by Teraoka et al. (1981). However, they lie in the strike side of the Hyuga Group south of the Ichifusa Dam, and the sandstone is so quartzose as compared with those of the Shimanto Supergroup. So, they are included in the Hyuga Group in this paper, despite yielding no fossils.

The mudstone of the Hyuga Group yields Eocene radiolarians at two localities south of Mt. Hanatate. The mudstone at Loc. 5 yields Thyrsocyrtis triacantha, Lychnocanoma babylonis, and Theocampe cf. pirum, which show Thyrsocyrtis triacantha Zone-T. bromia Zone of RIEDEL \& SANFILlippo (1978), and the mudstone at Loc. 6 yields Podocyrtis chalara and Theocampe mongolfieri, which show Podocyritis mitra Zone- $P$. chalara Zone. The group in the Hyuga Area yields many radiolarians and planktonic foraminifers of Eocene to Oligocene age (SAKAI et al., 1984). The mudstone at Loc. 4 yields molluscan fossils such as Lucinoma sp. and Yoldia sp. of latest Oligocene to early Miocene age (Tamura \& Harada, 1971). 


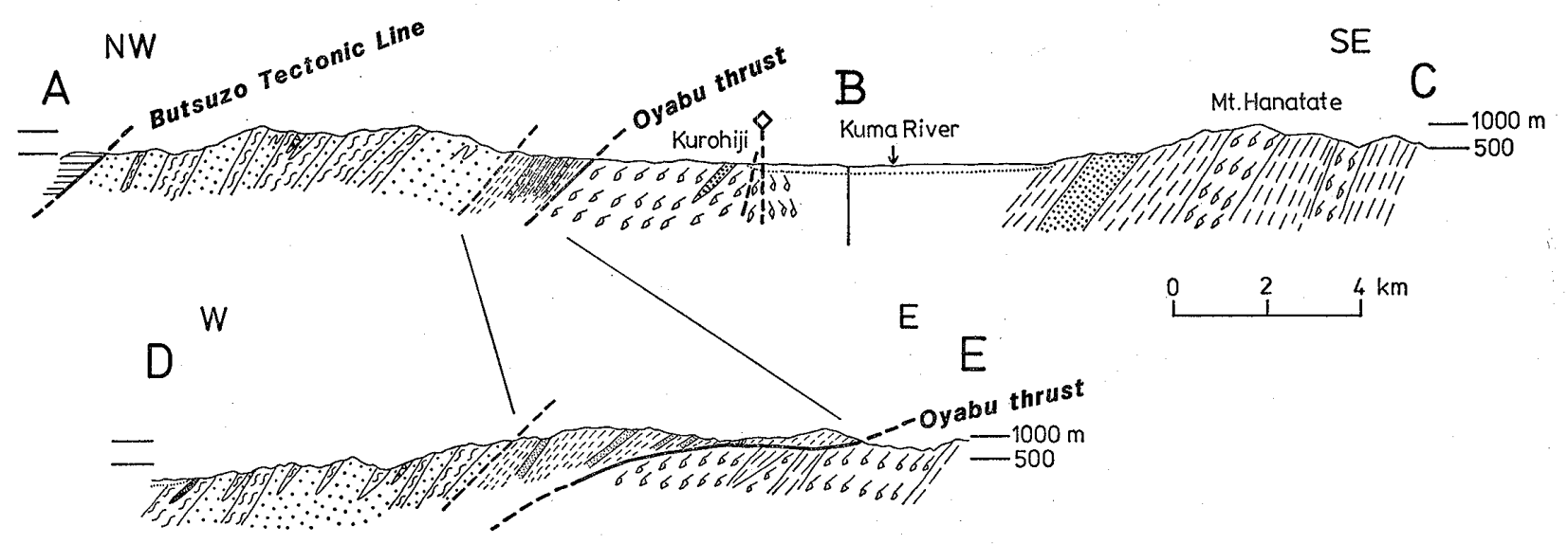

Fig. 3. Geologic profiles of the Hitoyoshi Bending Area.

\section{Pre-bending structures of the Sambosan, Shimanto, and Hyuga Terrains}

\section{Sambosan Terrain}

The Sambosan Group strikes $\mathrm{N} 40^{\circ}-70^{\circ} \mathrm{E}$ and dips at $40^{\circ}-70^{\circ}$ toward $\mathrm{N}$, and frequently shows normal facing. Chert and sandstone of the same horizon occur repeatedly by smaller scale thrusts verging southeastward (MURATA, 1981).

The Shiraiwayama thrust in the Sambosan Terrain is a large overthrust, which was formed probably at the time between Latest Gretaceous and Middle Eocene (Fig. 1). The thrust has moved not only the limestones of the northern Sambosan Terrain, but also the granitic rocks and Silurian strata of the Kurosegawa Terrain (Murata, 1981). The Shiraiwayama nappe along the Shiraiwayama thrust separates itself into four subnappes, S1S4 nappes from east to west, and they are arranged in a left-handed echelon pattern. Therefore, the strata of the Kurosegawa Terrain and northern Sambosan Terrain show the echelon pattern distribution on the geologic map. In the area north of the Hitoyoshi Bending, the S4 nappe to the west is in contact with the S3 nappe to the east, and the former is further thrust southeastward than the latter like a tear fault. The left-handed echelon pattern of the Kurosegawa Terrain and northern Sambosan Terrain was formed in the time of the thrusting, and it has no relation to the Hitoyoshi Bending.
On the other hand, no echelon pattern is observed in the southern Sambosan Terrain and the southern marginal Sambosan Terrain. Limestone-basic volcanics facies strata in the latter terrain on the north of the Butsuzo Tectonic Line are nearly parallel to the Shimanto Supergroup.

\section{Shimanto Terrain}

The Nonowaki and Tashiro Groups in the area north of Taragi generally strike $\mathrm{N} 45^{\circ}-$ $65^{\circ} \mathrm{E}$ and $\operatorname{dip} 45^{\circ}-70^{\circ} \mathrm{N}$, in spite of swinging of their strikes partly by later folding. The groups in the area southwest of Taragi strike $\mathrm{N} 40^{\circ} \mathrm{E}-\mathrm{N} 20^{\circ} \mathrm{W}$ and $\operatorname{dip} 30^{\circ}-60^{\circ} \mathrm{W}$ (Fig. 2). The Nonowaki Group shows northwestward or westward facings, and forms a homoclinal structure apparently, in spite of occurrence of some small scale overturned folds of southward vergence. However, there are possibly several thrusts between the sandstone-dominant and slump breccia-dominant formations because the former occurs repeatedly with northwestward facings. These thrusts are not accompanied by clear shear zones.

The Tashiro Group forms also a homoclinal structure, and it strikes parallel to the Nonowaki Group (Fig. 3). The Tashiro Group is probably in fault contact with the Nonowaki Group, because their lithofacies are different from each other.

\section{Hyuga Terrain}

The Shimanto Supergroup is thrust over the Hyuga Group along the Oyabu thrust. The thrust runs from east of Yunomae to south of Mt. Hirokai striking $\mathrm{NW}_{2}$ from 


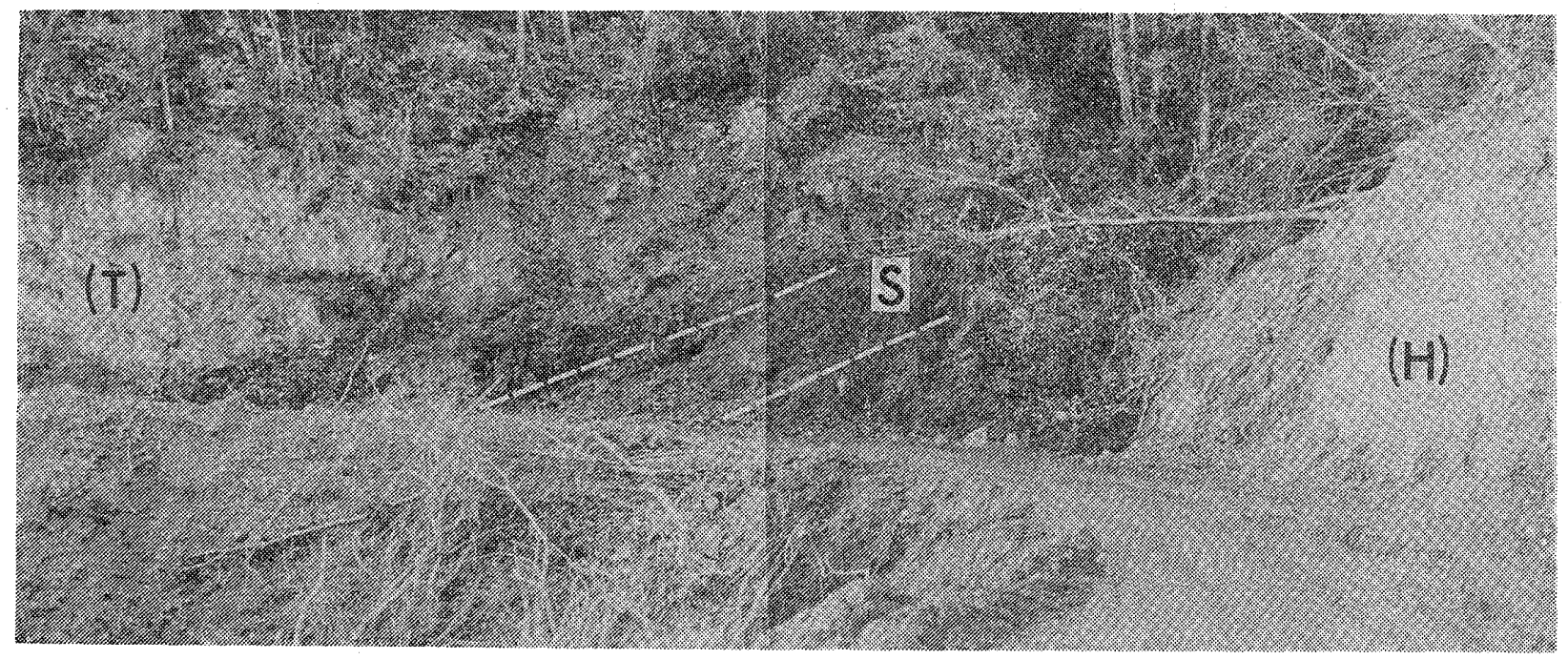

Fig. 4. The Oyabu thrust at Loc. 7 along the logging road to the east of Mt. Shiraga-dake. Chert-laminite and schistose sandstone of the Tashiro Group ( $T$ ) are thrust over slump breccia of the Hyuga Group $(\mathrm{H})$. S: shear zone.

south of Mt. Hirokai to east of Tashiro striking NE, and from east of Tashiro to east of Mt. Shiraga-dake roughly striking N-S (Fig. 2). It is a fairly low angle thrust dipping at about $15^{\circ}$ to $45^{\circ}$ toward NE, NW, and $\mathrm{W}$ (Figs. 2 and 3). It seems nearly horizontal near Mt. Shiraga-dake, because its trace is nearly concordant with the contour line. The Shimanto Supergroup and the Hyuga Group on the both sides of the Oyabu thrust strike nearly parallel to each other. The Oyabu thrust is observed at Loc. 7 to the east of Mt. Shiraga-dake (Fig. 2). Schistose sandstone and chert-laminite of the Tashiro Group are thrust over slump breccia of the Hyuga Group there (Fig. 4). Shear zone of $2 \mathrm{~m}$ wide strikes $\mathrm{N} 40^{\circ} \mathrm{W}$ and dips $30^{\circ} \mathrm{SW}$. The dip is fairly steeper than expected horizontal one by its trace parallel to the contour line. Dip-slip striation is observed in the shear zone, and many quartz veins are observed in and near the shear zone.

According to Teraoka et al. (1981), the Nobeoka Tectonic Line runs in the areas east of Taragi and near Mt. Shiraga-dake, and it bounds the Cretaceous Shimanto Supergroup from the Paleogene Hyuga Group. However, the Line is situated in the distributional area of the Tashiro Group of this paper, and there are no changes of lithofacies on the both sides of the Line. On the other hand, the Oyabu thrust of Teraoka et al. (1981) near Mt. Shiraga-dake nearly corresponds to the boundary thrust between the Shimanto Supergroup and the Hyuga Group of this paper, although they considered it a large overthrust in the Paleogene Hyuga Terrain. So, I called the boundary thrust between the Shimanto and Hyuga Terrains the Oyabu thrust.

The Hyuga Group seems to form the homoclinal structure with northwestward facings fundamentally. In spite of the complexity from development of slump structure and from abrupt strike changes by later folding, some large scale overturned folds with southeastward vergence are detected in the area northeast of Mt. Hanatate.

\section{Strilke swings and conical folds in the Shirianto and Hyuga Terrains}

\section{Stroile swings}

In the Hitoyoshi Bending Area, a remarkable strike swing occurs northeast of Taragi, where the strike swing of the Shimanto Supergroup occurs abruptly from NE to NW (Fig. 1). Teraoka et al. (1981) called the major scale strike swing the Hitoyoshi Bending. However, the Hitoyoshi Bending is not a single strike swing, but it is accompanied by several strike swings of smaller scale. Besides the swing northeast of Taragi, the Supergroup swings strike six times from NE to NW 
in the area northeast of Taragi, and two times southwest of Taragi (Fig. 2). In the areas where the strike swings occur, the hinge line of the strike swing is detected as a kind of plunging anticline and syncline (Fig. 2).

In the area northeast of Taragi, the Tashiro Group swings strike abruptly from NE to NW, bounded by an E-W trending fault (Fig. 2). The group on the northern side of the fault strikes NE and dips at $30^{\circ}$ to $70^{\circ}$ toward NW, whereas the group on the southern side strikes NW to N-S and dips at $20^{\circ}$ to $80^{\circ}$ toward SW to W. This abrupt strike swing is detected as an anticline which might have an $\mathrm{E}-\mathrm{W}$ hinge line, although it is modified by the $\mathrm{E}-$ W fault. Not only the Tashiro Group, but also the Nonowaki Group and the Hyuga Group are affected by the anticline described above. So, the trace of the Oyabu thrust curves there, and further south it runs east of Mt. Shiraga-dake, striking N-S.

There are three sets of anticline and syncline with 0.5 to $1.5 \mathrm{~km}$ half wavelengths in the area north of Taragi (Fig. 2). The beds generally strike $\mathrm{NE}$ and dip at $30^{\circ}$ to $80^{\circ}$ toward NW in the eastern limb of the syncline (in the western limb of the anticline). They swing strike gradually into $\mathrm{E}-\mathrm{W}$ in the hinge zone, and further into NW, dipping at the same angles toward $\mathrm{N}$ or NE. The folds have rather rounded hinge zones and planar limbs (Fig. 2). The hinge lines of these folds trend NNW and curve slightly on the map. The central anticline and syncline can be detected in the northern half of the Shimanto Terrain, and they can not be traced further south.

The hinge lines of the folds can be traced further north in the Sambosan Terrain, except for the western anticline which becomes hard to detect in the northern Shimanto Terrain. So, the Butsuzo Tectonic Line near Kureko, a large overthrust dipping at about $45^{\circ}$ toward NW, is affected by these folds, especially by the eastern and central anticlines, and has a bow-shape trace with convex side toward N. Such a bow-shape trace of the Line is observed only there in Kyushu. These folds are detected in the southern half of the southern
Sambosan Terrain indicated by strike swings of chert beds. But further north they are hard to be detected.

The western anticline can be traced further south, and the Hyuga Group is also folded (Fig. 2). The Oyabu thrust is folded near Mt. Hirokai. The trace of the Oyabu thrust abruptly curves there from NW strike to NE strike. The eastern anticline and syncline, and western syncline slightly affect the Oyabu thrust.

There are similar slight strike swings near Nonowaki, which are indicated by a set of faint anticline and syncline. The hinge lines possibly trend NW (Fig. 2). In the area southwest of Taragi, small strike swings possibly occur, because slump breccia-dominant formation of the Nonowaki Group of the same horizon is arranged in echelon pattern in the area west of and southwest of Taragi. Supposed anticline and syncline have $\mathrm{E}-\mathrm{W}$ trending hinge lines similarly to those in the Hyuga Terrain further east.

\section{Conical folds}

As the Shimanto Supergroup before bending is considered to have formed the homoclinal structure apparently like the supergroup in the Hyuga area with no bending (SAKAI \& KANMERA, 1981), an analysis of bedding surfaces is useful for determining fold geometry formed by bending. Bedding surface poles of the Shimanto Supergroup are plotted from five small segments in the Hitoyoshi Bending Area $\left(\mathrm{A}, \mathrm{B}, \mathrm{C}, \mathrm{C}^{\prime}\right.$, and $\mathrm{D}$ in Fig. 5).

As mentioned already, an abrupt strike swing occurs in the area northwest of Taragi. Net $B$ is from the north segment of this swing, and Net $\mathrm{C}$ is from south segment. Net B plus double Net $G$ is Net $C^{\prime}$, which can express strike swing from $B$ area to $C$ area. It is because the number of attitude of $\mathrm{C}$ area is about half of $B$ area. Net $C^{\prime}$, covering the abrupt strike swing, shows that the beds in the north of the $\mathrm{E}-\mathrm{W}$ fault strike $\mathrm{N} 40^{\circ}-80^{\circ} \mathrm{E}$ to $\mathrm{E}-\mathrm{W}$ and dip at $30^{\circ}$ to $70^{\circ}$ toward NW or $\mathrm{N}$, whereas those in the south strike $\mathrm{N}-\mathrm{S}$ to NW and dip $20^{\circ}$ to $80^{\circ}$ toward $W$ or SW except for the western part of segment C. They do not concentrate in N-S direction, 

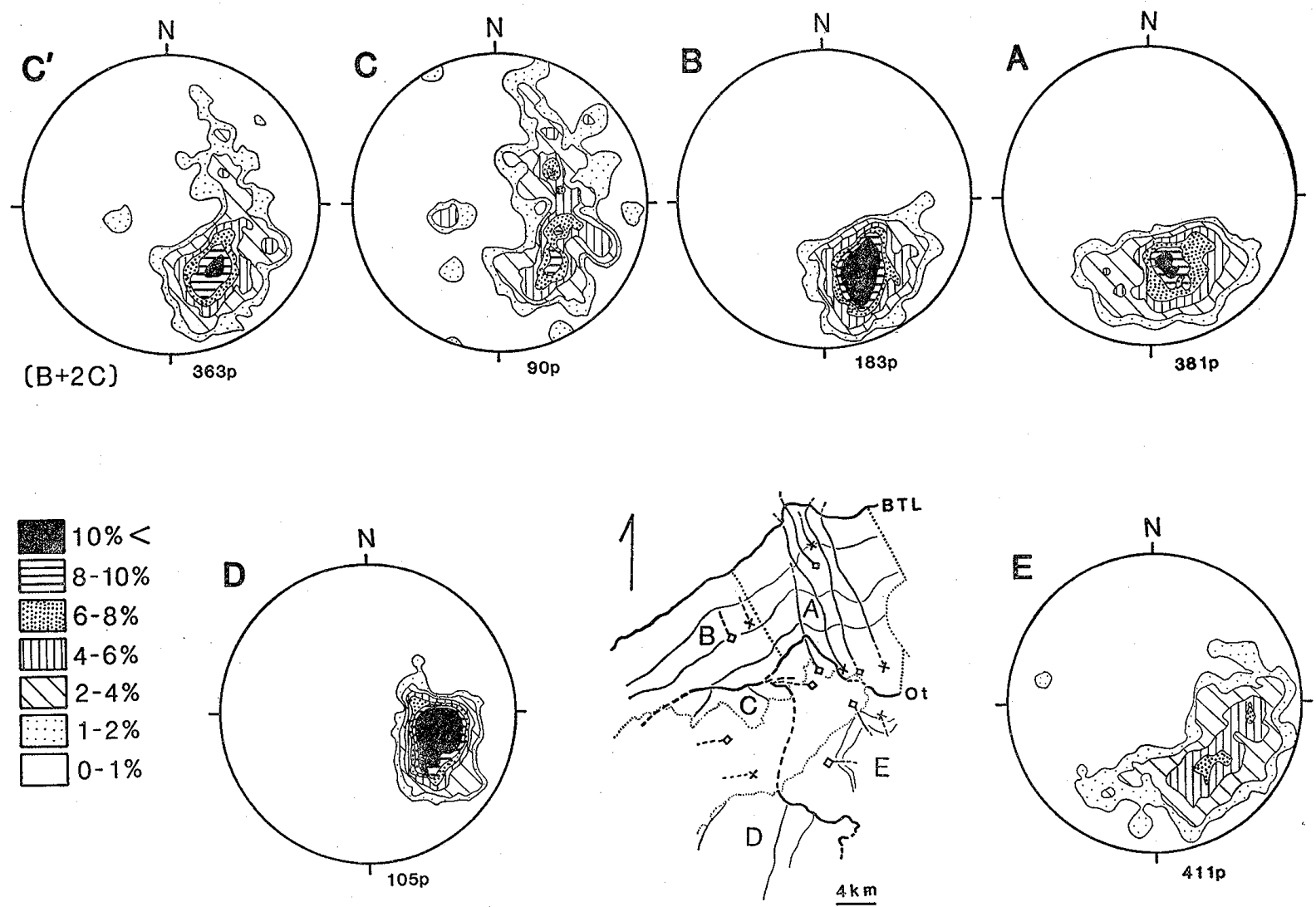

Fig. 5. Contour diagrams of bedding surface poles of the Shimanto Supergroup (A-D) and Hyuga Group (E). Schmidt Net. Lower hemisphere.

because the hinge zone was modified by the E-W fault and was missed. The bedding surfaces on the northern side of the fault are representative ones in the Shimanto Terrain to the northeast of the Hitoyoshi Bending in Kyushu. Net D covers the area further south than $\mathrm{Net} \mathrm{C}$, where the beds strike $\mathrm{N} 0^{\circ}-45^{\circ} \mathrm{E}$ and $\operatorname{dip}$ at $20^{\circ}$ to $70^{\circ}$ toward $\mathrm{W}$.

Net A covers the northeastern half of the Bending, where the three sets of anticline and syncline occur, having NNW trending hinge lines. The beds generally strike NE and dip at $30^{\circ}$ to $80^{\circ} \mathrm{NW}$ in the eastern limb of the synclines. They swing strike gradually into $\mathrm{E}-\mathrm{W}$ in the hinge zone, and further into NW in the western limb of the synclines.

The bedding surface poles on Net $\mathrm{A}$ and Net $\mathrm{C}^{\prime}$ might be considered to lie on a great circle whose pole plunges at $45^{\circ}$ to the $\mathrm{N}$, and at $30^{\circ}$ to the $W$ respectively (Fig. 6a). These two sets of folds are very similar to each other in that they affect both the Shimanto Super- group and the Hyuga Group after the movement of the Oyabu thrust. Two anticlines with different axes, $\mathrm{N}-\mathrm{S}$ trend one near $\mathrm{Mt}$. Hirokai and $\mathrm{E}-\mathrm{W}$ trend one west of Kurohiji, appear to join with each other near Taragi, although they are not confirmed from bad exposures. It is unlikely that two sets of folds with different axis directions were formed contemporaneously by a cylindrical folding, because two sets of fold axes are diagonal to each other. Fig. $6 b$ shows $2 \%$ contour line of each Net. It would seem that these bedding surface poles are best interpreted as lying on a small circle, which represents a cone of apical angle about $45^{\circ}$, and a cone axis is nearly vertical. Furthermore Net $\mathrm{E}$, covering the whole Hyuga Group, shows that the beds do not lie on a great circle, but they lie on the same small circle as Net $A$ to $D$. This clearly suggests that conical folds develop in the study area.

Conical folds are formed by a cylindrical 


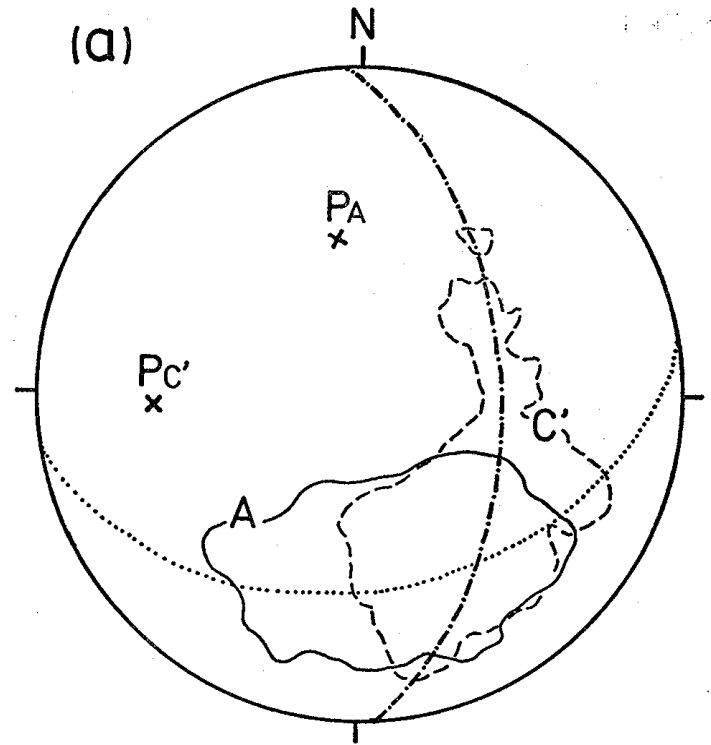

great circle girdle $(\cdots . .)$.$\& pole \left(P_{A}\right)$ of $A$ great circle girdle $(-\rightarrow)$ \& pole ( $\left.P C^{\prime}\right)$ of $C^{\prime}$

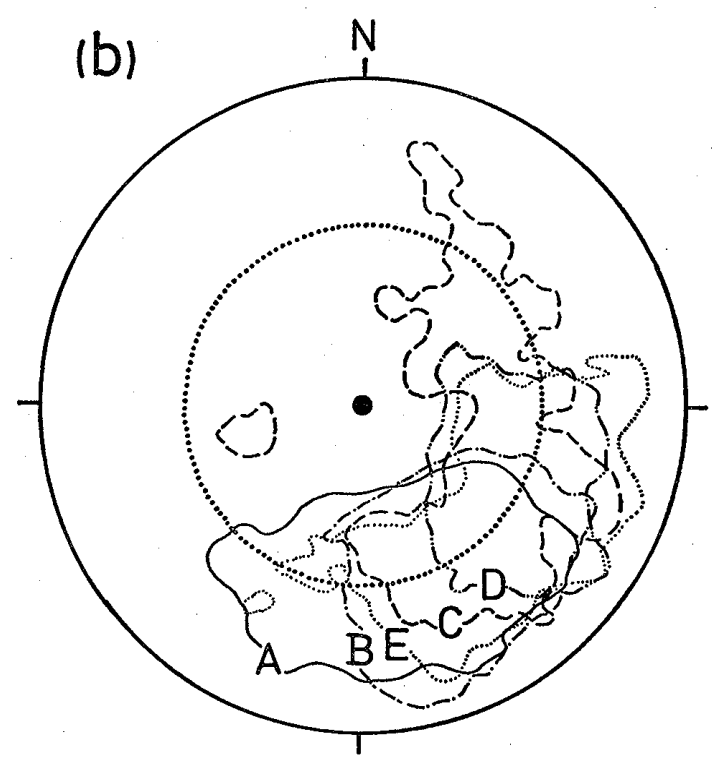

small circle girdle $(\cdots . .$.$) \& cone axis (1$

Fig. 6. Analyses of bedding surfaces. Schmidt Net. Lower hemisphere. (a) $2 \%$ contour lines of Net $\mathrm{A}$ and $\mathrm{C}^{\prime}$ are shown. (b) $2 \%$ contour lines of Net $\mathrm{A}$ to $\mathrm{E}$ are shown.

folding of a surface about an axis lying obliquely to that surface, or at tapering ends of a cylindrical fold (StTAuffer, 1964; Rickard, 1963). The conical folds of the Hitoyoshi Bending Area are not formed at the latter case, because they occur in the whole Bending Area. The conical folds with a cone of apical angle $45^{\circ}$ and a vertical cone axis are formed by a cylindrical folding of already inclined bedding surfaces, whose fold axis is vertical. The hinge lines of anticlines are situated in the hinge zone of cylindrical fold with vertical axis, whose convex side faces toward the continental side (north), and those of synclines are in the concave side (Fig. 7). It is reasonable that the Sambosan Group, the Shimanto Supergroup and the Hyuga Group, each dipping toward the continental side, were juxtaposed nearly parallel from the continental side to the oceanic side, and that they were folded by a vertical cylindrical folding. The cylindrical folds with NNW axial surfaces and those with $\mathrm{E}-\mathrm{W}$ axial surfaces are possibly conjugate fold set.

The Tashiro Group of the Shimanto Supergroup possesses weak stretching lineations on foliation surfaces which are subparallel to the bedding surfaces. They are well observed

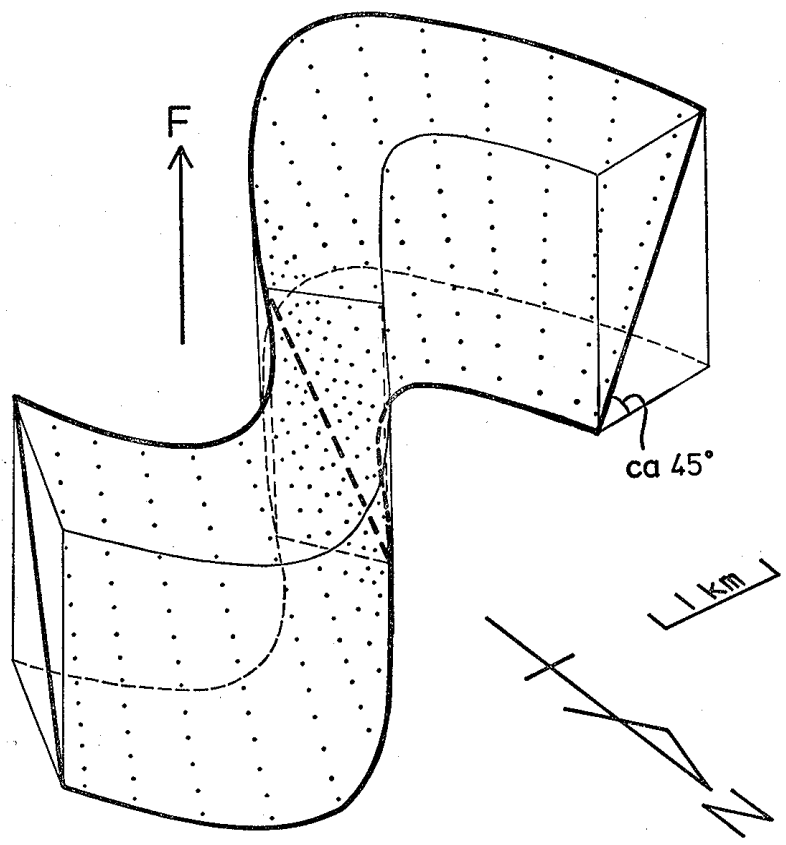

Fig. 7. Conical folds with a cone of apical angle $45^{\circ}$ and a vertical cone axis. They are formed by a cylindrical folding of already inclined bedding surface (dotted).

along the Kawabe River near Tashiro, and trend subparallel to the dip direction. However, in other area, lineations are very weak 
and it is very difficult to analyze the relation between lineation pattern and conical folds. It is future problem to be solved.

\section{Formation of conical folds and clockwise rotation of the Southwest Japan Arc}

The Permo-Jurassic Sambosan Group, Cretaceous Shimanto Supergroup, and Paleogene to earliest Miocene Hyuga Group are all affected by the cylindrical folds with vertical axes, which formed the conical folds in the Hitoyoshi Bending Area. So, the cylindrical folds were formed after the parallel juxtaposition of these terrains, which had formed the homoclinal structures apparently.

The earliest Miocene strata, the youngest in the Hyuga Terrain, which is affected by the bending, are confirmed in the Nichinan area, southeast of the Hitoyoshi Bending Area. The Shimanto Supergroup and the Hyuga Group were discordantly intruded by the Middle Miocene (14 Ma) granites, after they were affected by the Bendings. The fact is well confirmed in the Hokusatsu Bending Area, where the oblate Shibisan Granite intrudes the bent Shimanto Supergroup (Наsнimoto, 1962a,b). Therefore, the cylindrical folds with vertical axes were formed in the time between earliest Miocene and Middle Miocene.

The Oyabu thrust runs from the Morotsuka area of East Kyushu, to the Hitoyoshi Bending Area of South Kyushu (Fig. 1). The thrust possibly extends further south to the east of Mt. Takakuma (Fig. 1) from the following facts. The Takakumayama Belt of Hashimoto (1962b) and Teraoka (1979) in South Kyushu consists of chert-laminite-dominant strata and is the southern extension of the Tashiro Group of the Bending Area. To the east of the Takakumayama Belt, the Nichinan Group, equivalent to the Hyuga Group, is juxtaposed with the same trends.

The Oyabu thrust strikes NE approximately and dips NW in East Kyushu, east of the Hitoyoshi Bending Area, and it strikes N5 $15^{\circ} \mathrm{E}$ and dips $\mathrm{W}$ in South Kyushu, south of the area. The thrust changes strike mainly in the Hitoyoshi Bending Area, and its strike is relatively stable except in the Bending Area.
It is known that large underthrusts in the subduction zone are formed initially curved in the juction area between two arc systems. However, the Oyabu thrust was not formed in the state of being remarkably curved originally, because the hinge lines of the strike swings can be traced across the thrust. The Oyabu thrust was folded together with the Shimanto and Hyuga Terrains after the thrusting.

It is reasonable that the Oyabu thrust was fairly planar and had a linear thrust trace originally, because a thrust of fairly large extent is formed in the state of rather stable stress field, althouth it is ordinarily slightly curved.

Besides the Oyabu thrust, the Butsuzo Tectonic Line, which is a large overthrust formed in the time between latest Cretaceous and Middle Eocene, strikes NE approximately and dips NW in East Kyushu, and it strikes $N 5^{\circ}-$ $20^{\circ} \mathrm{E}$ and possibly dips $\mathrm{W}$ in South Kyushu. Furthermore, not only the Shimanto and Hyuga Terrains but also the Ryoke Terrain, Kurosegawa and Sambosan Terrains all swing their trends from NE trends in East Kyushu, to nearly $\mathrm{N}-\mathrm{S}$ trends in South Kyushu by the Hokusatsu Bending to the west of the Hitoyoshi Bending Area. It is reasonable that all the terrains were juxtaposed nearly parallel with rather linear trends from the Southwest Japan Arc to the Nansei-Shoto Arc, because they have the same structures in both arcs.

The Southwest Japan Arc is considered by many workers to have been rotated clockwise in association with the opening of the Sea of Japan behind it, although opinions are diverse concerning the time and angle of the rotation. This idea is mainly based on that the Hida Terrain was formerly linked to the ChinoKorea Massif. On the other hand, the Nansei-Shoto Arc is nearly parallel to the shelf edge of China Continent, bearing the Okinawa Trough between them.

The cylindrical folding with vertical axes in the Hitoyoshi Bending Area was possibly formed associated with the clockwise rotation of the Southwest Japan Arc. If an arc is rotated against to a fixed arc, a bending could be detected as a fold of large scale, whose axial 


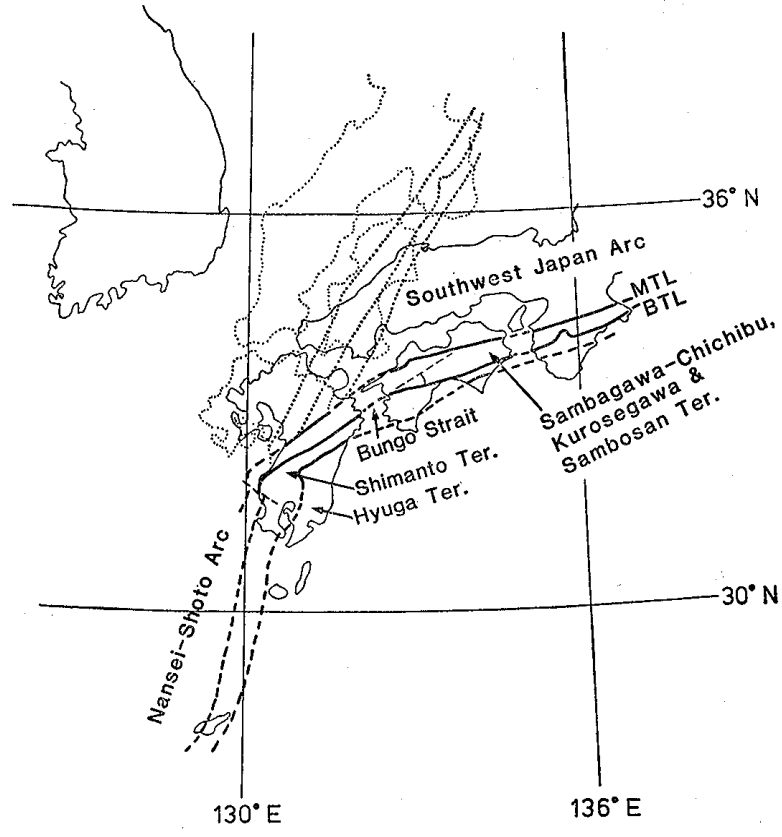

Fig. 8. Glockwise rotation of Southwest Japan Arc in the Miocene time. MTL: Median Tectonic Line, BTL: Butsuzo Tectonic Line.

part is a bending area, and whose limbs are two arcs. The fold is expected to be a cylindrical one with a vertical axis. Namely, a rotation in a horizontal surface means a cylindrical folding with a vertical axis (Fig. 8).

The cylindrical folds of small scale in the Hitoyoshi Bending Area are considered to have been formed associated with a large scale folding caused by the rotation of the Southwest Japan Arc, because they possess the vertical axes, the same as an expected large scale one. The conical folds detected in the Bending Area are possibly characteristic fold styles associated with the rotation of arc.

The rotation angle of the Southwest Japan Arc is about $30^{\circ}$ clockwise in Kyushu, judging from the strike swing of the all Terrains. The Southwest Japan Arc strikes N65 - $70^{\circ} \mathrm{E}$ in Shikoku and Kii Peninsula, although it strikes $\mathrm{N} 50^{\circ}-55^{\circ} \mathrm{E}$ in Kyushu to the east of the Hitoyoshi Bending (Fig. 8). The difference of strikes between two districts is not negligible, because the Arc is quite linear in both districts and the strike swing occurs near the Bungo Strait. It is another bend of the Arc. So, the rotation angle of the Southwest
Japan Arc in Shikoku and Kii Peninsula is expected about $45^{\circ}$, supposing that the Terrains of the Outer Zone was nearly linear originally (Fig. 8).

The recent extensive paleomagnetic studies revealed that the Southwest Japan Arc rotated clockwise at about $58^{\circ}$ (Otofuji \& Matsuda, 1983) and at $45^{\circ}$ (Hayashida \& Iтo, 1984). These paleomagnetic data were obtained from the area in and to the north of Shikoku and Kii Peninsula. The rotation angle inferred from the geologic evidence nearly corresponds to the paleomagnetic data. The paleomagnetic data show that the main rotation occurred in Late Oligocene to Miocene time (Otofuji \& Matsuda, 1983). Furthermore, TORII et al. (1985) insisted that the rotation had occurred in Middle Miocene (about 15 $\mathrm{Ma}$ ) in a very short time such as about $1 \mathrm{Ma}$. These data are consistent with my above mentioned consideration, although geological evidence can not detect such a minute time interval.

\section{Summary}

(1) In the Hitoyoshi Bending Area, the strike swings of the Shimanto Supergroup are detected as hinge lines of some kind of anticlines and synclines. These folds affect the Sambosan, Shimanto, and Hyuga Terrains which were initially juxtaposed nearly parallel with one another.

(2) Bedding surface analyses of the Shimanto Supergroup show that these folds are conical folds. The conical folds were formed by a cylindrical vertical folding of strata which had dipped toward the continental side.

(3) The cylindrical folds with vertical axes were formed associated with the clockwise rotation of the Southwest Japan Arc. They were formed in Early to Middle Miocene. The rotation angle is about $30^{\circ}$ in Kyushu and about $45^{\circ}$ in Shikoku and Kii Peninsula.

\section{Acknowledgements}

I would like to thank Assoc. Prof. Ken-ichi Kano of the Shizuoka University for his discussion and critical reading of the manuscript. I am grateful to Prof. A. Irjima, Assoc. Prof. S. 
Yoshida, Dr. T. Ito, and Mr. S. Yamakita of the University of Tokyo for their discussion. I am also grateful to Assoc. Prof. T. SAkaI of the Utsunomiya University, and Assoc. Prof. M. AdAari and Mr. H. Yoshida of the Nagoya University for identification of Paleogene and Cretaceous radiolarians.

\section{References}

HAshimoto, I., 1962a: Geological succession and structure of the undated strata in the Hokusatsu district, Kagoshima Prefecture. Rep. Ear. Sci. Dep. Gen. Educ., Kyushu Univ., 8, 47-62.*

, 1962b: The sedimentary complex of uncertain ages in South Kyushu. Ibid., 9, 13-69.*

Hayashida, A. and Iто, Y., 1984 : Paleoposition of Southwest Japan at $16 \mathrm{Ma}$ : Implication from paleomagnetism of Miocene Ichishi Group. Earth Planet. Sci. Lett., 68, 335-342.

Hilde, T. W. C. and Wageman, J. M., 1973 : Structure and origin of the Japan Sea. In Coleman, P. J., ed., The Western Pacific, 415-434.

HonzA, E., 1979 : Sediments, structure and origin of Japan Sea : Concluding Remarks. In E. Honza, ed., Cruise Rept., 13, Geol. Surv. Japan, 89-93.

Kaseno, Y., 1972 : On the origin of the Japan Sea Basin. 24th Int. Geol. Cong., Montreal, [8], 37-42.

KimurA, T., 1974: The ancient continental margin of Japan. In Burk, C. A. and Drake, C. L., eds., The Geology of Continental Margins, 817-829.

- 1979 : Japanese Islands : the geological history, II-A. Kokon-shoin, Tokyo.**

Kobayashi, T., 1956 : The insular arc of Japan, its hinter basin and its linking with the PeriTunghai arc. Proc. 8th Pacific Sci. Congress, II-A, 799-807.

Murata, A., 1981 : Large decke structures in the Kurosegawa and Sambosan terrains, in Kyushu, Southwest Japan. Jour. Fac. Sci., Univ. Tokyo, [II], 20, 277-293.

Nakasero, K. and Nishmura, A., 1981 : Upper Jurassic and Cretaceous radiolaria from the Shimanto Group in Southwest Japan. Sci. Rep., Col. Educ. Osaka Univ., 30, 133-203.

NodA, M. and Hashimoto, I., 1958 : The geological structure of Okawachi district, Shiiba-mura, Higashi-Usuki-gun, Miyazaki Prefecture. Rep. Ear. Sci., Dep. Gen. Educ., Kyushu Univ., 5, 17-24.*

Ogawauchi, Y., Iwamatsu, A., and Tanabe, A.,
1984 : Stratigraphy and geologic structures of the Shimanto Supergroup in the northeastern part of Nobeoka City, Miyazaki Prefecture, Japan. Rep. Fac. Sci., Kagoshima Univ., no. 17, 67-88.*

OKUDA, Y., 1984 - Tectonic evolution of the continental margin off Southwest Japan during the Late Cenozoic. Rep. Tech. Res. Cent., J.N.O.C., 19, 33-93.

Otofuji, Y. and Matsuda, T., 1983 : Paleomagnetic evidence for the clockwise rotation of Southwest Japan. Earth Planet. Sci. Lett., 62, 349-359.

Rickard, M. J., 1963 : Analysis of the strike swing at Crockator Mountain, Co. Donegal, Eire. Geol. Mag., 100, 401-419.

Rredel, W. R. and Sanfillippo, A., 1978 : Stratigraphy and evolution of tropical Cenozoic radiolarians. Micropaleontology, 23, 61-96.

SAKAI, T. and KanmerA, K., 1981 : Stratigraphy of the Shimanto Terrain and tectono-stratigraphic setting of greenstones in the northern part of Miyazaki Prefecture, Kyushu. Mem. Fac. Sci., Kyushu Univ., Geology, 14, 31-48.*

- Nishi, H., SaIto, T., Nakaseko, K. and Nishimura, A., 1984 : Microbiostratigraphy of the Paleogene System of the Shimanto Terrane in Kyushu. In SAìto, T., OkAdA, H. and KAIHO, K., eds., Biostratigraphy and international correlation of the Paleogene System in Japan, 95112.**

Sato, T., 1984 : On the radiolarian fossils. The fiscal 1983 report of investigations on cultural assets, associated with the construction of the Kawabe-gawa Dam, Itsuki Village of Kumamoto Pref., 30-41.**

ShibatA, K., 1978 : Contemporaneity of Tertiary granites in the Outer Zone of Southwest Japan. Bull. Geol. Surv. Japan, 29, 551-554.*

Shuto, T., 1963 : Geology of the Nichinan Area with the special reference to the Takachiho Disturbance. Mem. Fac. Sci., Kyushu Univ., 6, 135166.*

Stauffer, M. R., 1964 : The geometry of conical folds. N. Z. J. Geol. Geophys., 7, 340-347.

Tamura, M. and Harada, S., 1971 : Some molluscan fossils from the Shimanto Terrain of Kyushu, Japan. Mem. Fac. Educ., Kumamoto Univ., 19, 44-48.*

TeraokA, Y., 1979 : Provenance of the Shimanto geosynclinal sediments inferred from sandstone compositions. Jour. Geol. Soc. Japan, 85, 753- 
769.*

, Imai, I. and Okumura, K., 1981 : The bending structures of the Outer Zone of $\mathrm{K}$ yushu. Studies on Late Mesozoic Tectonism in Japan, 3, 8798.**

Toris, M., Hayashida, A. and Otofujr, Y., 1985 : The rotation of Southwest Japan and the formation of the Sea of Japan. Science (Kagaku), 55,
$47-52 . * *$

Yoshrda, S., 1982 : Chert-laminite : its petrographical description and occurrence in Japanese geosyncline. Jour. Geol. Soc. Japan, 87, 131$141 . *$

* : in Japanese with English abstract $* *$ : in Japanese

\begin{tabular}{|c|c|}
\hline Eshiro & Minakoshi .......... \\
\hline Furuyashiki …..........古屋敷 & Mt. Hanatate \\
\hline Hitoyoshi …................人吉 & Mt. Hirokai \\
\hline Ichifusa Dam ……市房ダム & Mt. Kanayama................ \\
\hline ………球磨川 & Mt. Shiraga-dake \\
\hline Kureko ……………久連子 & Nonowaki · \\
\hline Kurohiji $\quad \ldots . . . . . .$. & Oyabu thrust \\
\hline
\end{tabular}

MURATA, A., 1987 : Conical folds in the Hitoyoshi Bending, South Kyushu, formed by the clockwise rotation of the Southwest Japan Arc. Jour. Geol. Soc. Japan, 93, 91-105. (村田明 広, 1987 : 西南日本弧の回転により形成さ机た人吉座曲にみられる円錐形䙃曲. 地質雑，93，91-105.)

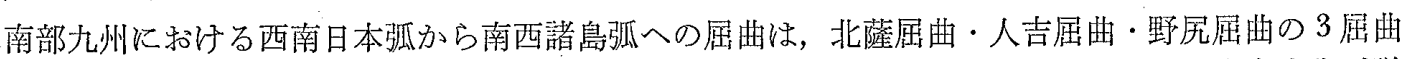
に代表される.それらのらち，人吉屈曲地域に抒いて，四万十累層群㧍よび日向層群の走向変化が詳 細に調べられた。走向変化を作っている䙫曲構造は，鉛直の円錐軸を持つ円錐形褔曲であることが幾

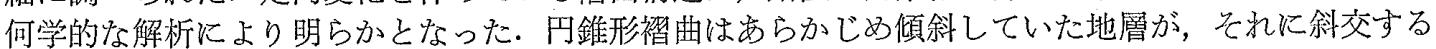
褶曲軸を持つ円筒状褶曲を受けた時に形成される。人吉屈曲地域で円錐形褟曲を生じさせた鉛值な軸 を持った円筒状褶曲は，西南日本弧の中新世に括ける時計回りの回転に佯って形成された。 